\title{
An Experimental Performance on Solar Photovoltaic Thermal Collector with Nanofluids for Sustainable Development
}

\author{
Srinivasulu Gundala $\mathbb{D}^{1}{ }^{1}$ M. Mahaboob Basha, ${ }^{2}$ V. Madhurima, ${ }^{3}$ N. Praveena, ${ }^{4}$ \\ and S. Venkatesh Kumar $\mathbb{i D}^{5}$ \\ ${ }^{1}$ Department of Electronics and Communication Engineering, Lakireddy Bali Reddy College of Engineering (Autonomous), \\ Andhra Pradesh, India \\ ${ }^{2}$ Department of Electronics and Communication Engineering, Sreenidhi Institute of Science and Technology, Hyderabad, India \\ ${ }^{3}$ Department of Electronics and Communication Engineering, SV Engineering College, Tirupati, India \\ ${ }^{4}$ Department of Information Technology, Velagapudi Ramakrishna Siddhartha Engineering College, Vijayawada, India \\ ${ }^{5}$ Department of Mechanical Engineering, College of Engineering and Technology, Mettu University, Ethiopia Po Box: 318
}

Correspondence should be addressed to Srinivasulu Gundala; srinivasulugundala46@gmail.com and S. Venkatesh Kumar; s.venkateshkumar@meu.edu.et

Received 24 August 2021; Revised 29 September 2021; Accepted 11 October 2021; Published 31 October 2021

Academic Editor: Lakshmipathy R

Copyright (c) 2021 Srinivasulu Gundala et al. This is an open access article distributed under the Creative Commons Attribution License, which permits unrestricted use, distribution, and reproduction in any medium, provided the original work is properly cited.

In this article, the photovoltaic thermal collector (PVT) have designed and fabricated using nanoparticle nanofluid. The cause of this is to check out the effect of using water and water-based totally graphene nanoplatelets at an awareness of $0.05 \mathrm{wt} \%$ on the performance of PVT structures. Outdoor assessments have been performed at quantity along with the float prices of $0.5 \mathrm{~L} / \mathrm{min}$ and $1.0 \mathrm{~L} / \mathrm{min}$ for the aforementioned nanofluids, respectively, using water as a reference fluid. The results that have been analyzed from an active angle confirmed and determined that, graphene water nanofluid achieved higher in phrases of photovoltaic active conversion, than water that might generate the first-class thermal performance sooner or later of the peak period of sun radiation and high mobile temperature. The inclusion of water in the PVT collector increases average daily electrical efficiency by $7.8 \%$, and $8.5 \%$ at flow rates of 0.5 LPM and $1.0 \mathrm{LPM}$, respectively. Furthermore, using water in the PVT collector increases average daily thermal efficiency by $24.9 \%$, and $26.3 \%$ at flow rates of 0.5 LPM and 1.0 LPM, respectively.

\section{Introduction}

Renewable energy such as solar, wind, hydro, biogas, tidal, and waves plays a vital role all over the world. Solar energy is one of the eminent renewable power resources that offer future technology properly [1]. The critical software of solar strength can be labeled into two kinds: sun thermal device, which renovates sun electricity to thermal energy, and photovoltaic (PV) device, which transfigures solar electricity to electric power [2]. Usually, the structures are used after the opportunity [3]. The combined shape of sun thermal and photovoltaic (PV) is thought to be a photovoltaic thermal (PVT) system [4]. A noteworthy study which works on PVT structures has been completed in the past 50 years [5,
6]. Increasing the temperature of a solar panel by way of one degree Celsius has been shown to result as zero $[7,8]$, five percent lower in electric performance for silicon cells [9]. As an end result, solar panels can be cooled using an expansion of coolants, along with water and nanofluids. The following arethe number of most trendy research that have been tested in this literature. Wolf [10] provided an idea of PV/T creditors for the first time and large observation has been carried out at the general performance of the module using experimental and theoretical techniques, with water-cooled flat-panel PV/T lenders, being frequently used .

Natrayan and Merneedi [11] pioneered the use of water or air as a fluid medium in a sun thermal collector. Sardarabadi et al. [12] performed a test in PVT systems using 
water, due to the fact that bottom fluid and $\mathrm{Sio}_{2}$ nanofluid at adaquate concentrations. They observed that, standard overall performance come to be 3.6 percent for $1 \mathrm{wt}$ percentage and 7.9 percent for $3 \mathrm{wt}$ percentage whilst in evaluation to PVT water. Ghadiri et al. [13] tested diverse portions of water and ferro fluid $\left(\mathrm{Fe}_{3} \mathrm{O}_{4} /\right.$ water $)$ in an indoor PVT device. In comparison to a PV gadget, the overall modified performance is proven to be 45 percent. Sardarabadi and Passandideh-Fard [14] combined three types of nanodebris $\left(\mathrm{Al}_{2} \mathrm{O}_{3}, \mathrm{TiO}_{2}\right.$, and $\left.\mathrm{ZnO}\right)$ with deionized water at an attention of $0-2 \mathrm{wt} \%$. The authors concluded that $\mathrm{TiO}_{2}$ and $\mathrm{ZnO}$ had higher electrical performance, and $\mathrm{ZnO}$ had higher thermal performance.

Al-Shamani et al. [15] investigated with the glide prices on diverse nanofluids together with $\mathrm{SiO}_{2}, \mathrm{TiO}_{2}, \mathrm{SiC}$, and water as a base fluid. According to the results, $\mathrm{SiC}$ had the very fantastic electric-powered performance around thirteen, fifty percent and usual performance of 81.73 percent. Soltani et al. [16] accomplished experimental research in a PVT device using a $\mathrm{Fe}_{3} \mathrm{O}_{4}$ /water nanofluid. It was concluded that preferred typical performance and electricity technology had been advanced by using the use of $13 \%$ and $52 \%$, respectively. The authors additionally confirmed that, using $\mathrm{SiO} 2$ stepped forward trendy, overall performance and electricity output is 3.35 percent and 54.29 percent, respectively.

Al-Waeli et al. [17] experimentally studied 3 varieties of water-based totally nanofluids consisting of $\mathrm{Al}_{2} \mathrm{O}_{3}, \mathrm{CuO}$, and $\mathrm{SiC}$ on photovoltaic thermal creditors. It ends up locating that $\mathrm{SiC}$ had better thermal conductivity than the alternative nanofluids. Natrayan et al. [18] achieved an experiment having an observation on the silica/water nanofluid and its overall performance in a PVT system. It is determined that overall performance and exergy might be stepped forward by way of $7.9 \%$ and $24.3 \%$, respectively. For lengthy-term stability, $\mathrm{Ag} /$ water nanofluid turn out to be dealt with through electric-powered explosion of wire $[19,20]$ and the device modified into evaluated the usage of thermodynamics, specifically power and energy performance.

This test turned into carried out with varied concentrations and glide regimes. The intention of this check is to draw interest to the use of carbon nanomaterials in improving the general performance of PVT systems. To the greatness of the author's understanding, graphene nanoplatelet nanofluid grows to be experimentally explored in this paper for nonconcentrating PVT tool and evaluates its typical overall performance. The authors examined in contrast the electric and thermal efficiency of water and the use of nanofluids on a PVT collector.

\section{Analytical Methodology}

Two kinds of energy analysis were carried out in this study such as electrical and thermal performance of PVT collector [21] as given below.

2.1. Electrical Energy Analysis. The electrical efficiency of a $\mathrm{PV} / \mathrm{T}$ system is typically used to decide its electric overall performance [22]. The most viable performance at a given solar intensity is received, through dividing the maximum
TABLE 1: Technical specification of PV panel.

\begin{tabular}{lc}
\hline Specification & Values \\
\hline$P_{p}$ & $260 \mathrm{~W}$ \\
$V_{\mathrm{mp}}$ & $30.18 \mathrm{~V}$ \\
$I_{\mathrm{mp}}$ & $7.96 \mathrm{~A}$ \\
$V_{\mathrm{oc}}$ & $36.72 \mathrm{~V}$ \\
$I_{\mathrm{sc}}$ & $8.99 \mathrm{~A}$ \\
$T_{\mathrm{lc}}$ & $0.045 \% \mathrm{~K}^{-1}$ \\
Single-cell dimension & $156 \mathrm{~mm} \times 156 \mathrm{~mm}$ \\
Single-module dimension & $1640 \mathrm{~mm} \times 992 \mathrm{~mm} \times 35 \mathrm{~mm}$ \\
\hline
\end{tabular}

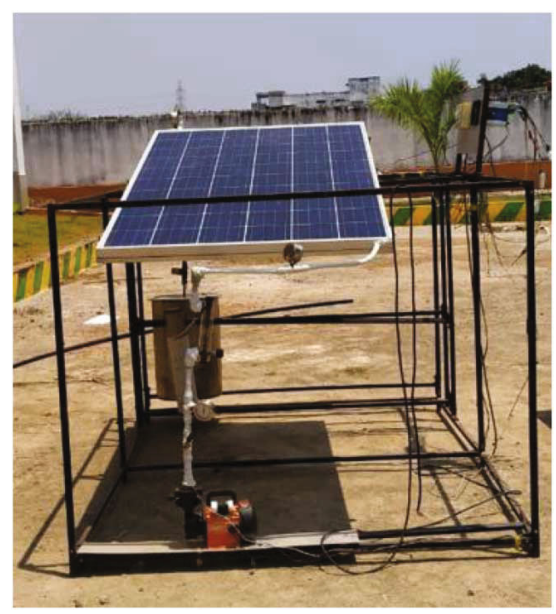

Figure 1: Photographic view of experimental setup.

appropriate electric-powered energy output of the PV module, with the useful resource of the sun intensity accomplishing the PV module's glazing surface [23].

$$
\eta_{\text {elec }}=\frac{P_{\max }}{Q_{s}},
$$

where $P_{\max }$ is the maximum electrical energy output from the PV module and may be calculated using Equation (2). The rate of solar energy received by the panel, which can be calculated using Equation (3).

$$
P_{\max }=I_{\mathrm{mp}} V_{\mathrm{mp}}
$$

where $I_{\mathrm{mp}}$ denotes the maximum current (amps) and maximum voltage (volts) of the panel.

$$
Q_{s}=A_{\mathrm{col}} I_{G}
$$

where $A_{\text {col }}$ is the area of the collector $\left(\mathrm{m}^{2}\right)$ and IG is the solar intensity $\left(\mathrm{W} / \mathrm{m}^{2}\right)$.

2.2. Thermal Energy Analysis. The term thermal efficiency is commonly used to describe the thermal performance of a 


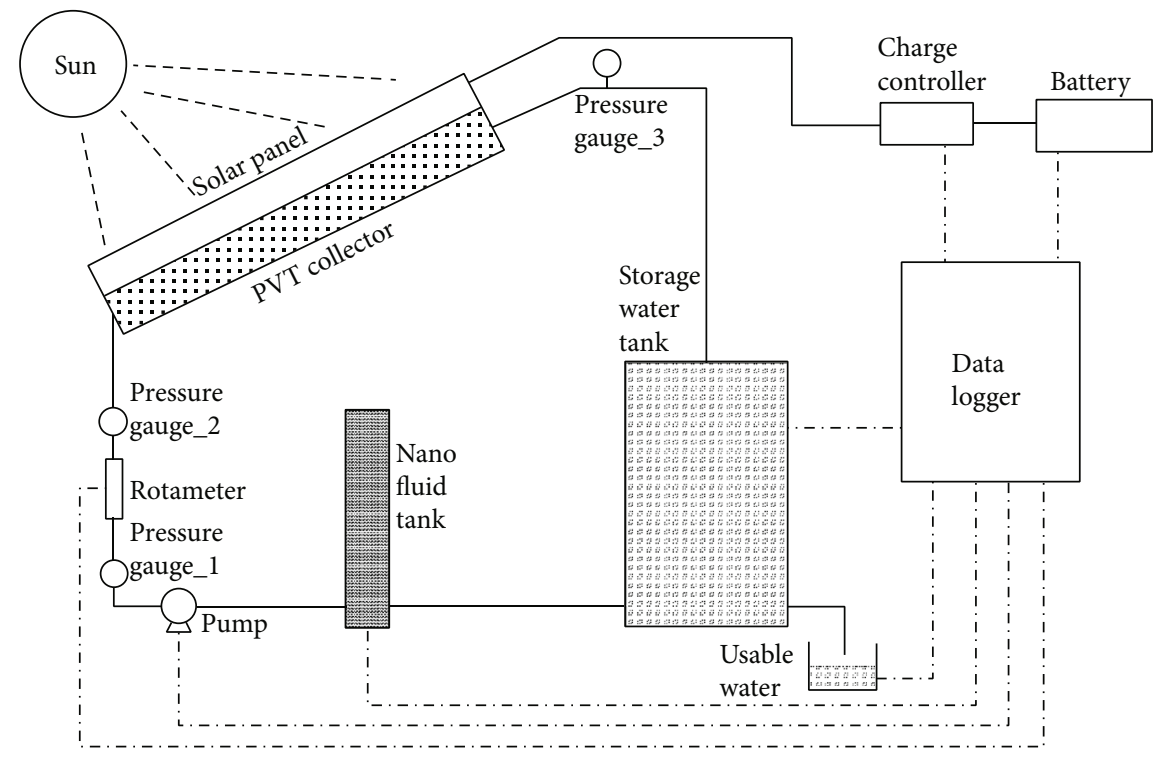

FIGURE 2: Schematic view of experimental setup.
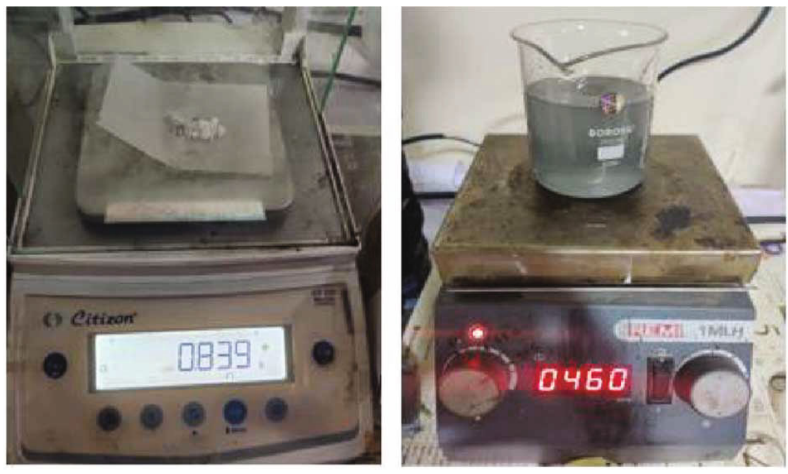

FIgURE 3: Preparation of nanoparticle and nanofluid during the laboratory.

$\mathrm{PV} / T_{\text {system }}$ [24]. The low temperature heat is created from the rear side of the solar panel (as shown by the equation below).

$$
\eta_{\text {ther }}=\frac{Q_{u}}{Q_{s}}
$$

where $Q_{u}$ is the rate of useful low temperature heat attained by the solar panel, which can be drawn from

$$
Q_{u}=m C_{p} \Delta T=m C_{p}\left(T_{o}-T_{i}\right),
$$

where $m$ is mass flow rate of the fluid $(\mathrm{Kg} / \mathrm{s}), C_{p}$ is specific heat capacity of the fluid $(\mathrm{kJ} / \mathrm{kg} \mathrm{K}), \Delta T$ is difference in temperature $(\mathrm{K}), T_{o}$ is the outlet fluid temperature $(\mathrm{K})$, and $T_{i}$ is the inlet fluid temperature $(\mathrm{K})$ [25].

2.3. Experimental Methodology. A photovoltaic thermal sun collector is made from a storage tank, a nanofluid tank, a water pump, a temperature gauge, and a pressure gauge

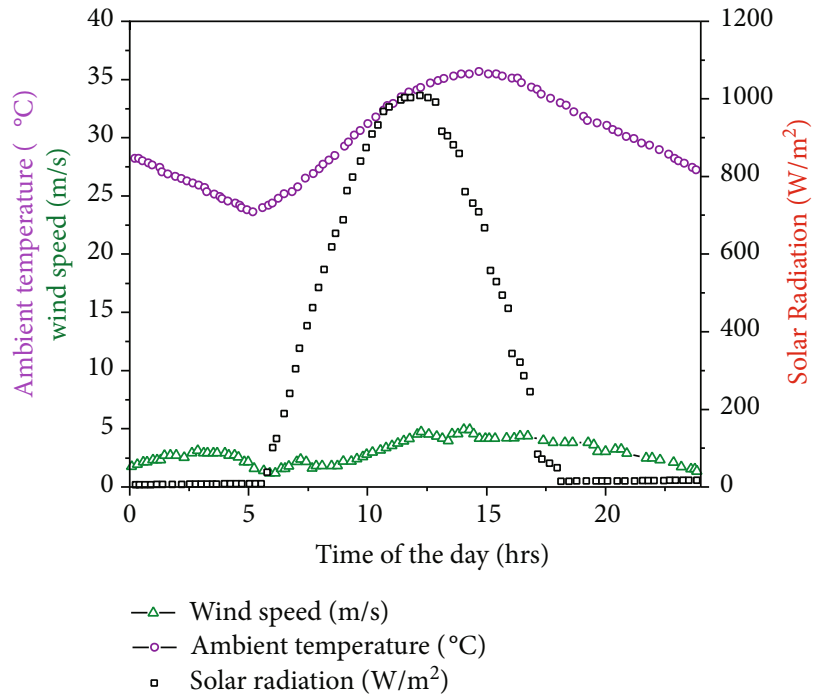

FIgURE 4: Average results of the solar radiation, ambient temperature, and wind speed at the experimental set up.

[26]. The outdoor dimensions of the PV/STSC tool are $1640 \mathrm{~mm}$ in period, $992 \mathrm{~mm}$ in width, and $35 \mathrm{~mm}$ in peak, with serpentine copper tube diameter and top of $6.35 \mathrm{~mm}$ and $1600 \mathrm{~mm}$, respectively [27]. The technical characteristics of the PV panel evaluated in these studies are confirmed in Table 1. A storage tank with an indoor diameter of $300 \mathrm{~mm}$ and a top of $500 \mathrm{~mm}$ becomes built out of chrome steel [28].

Glass wool insulation with a thickness of $0.07 \mathrm{~m}$ was put around the storage tank's perimeter and associated pipes. The flow rate of the HTF, as well as the system's intake and outlet pressure differential, was monitored with a rotameter and a pressure gauge. The temperature of the heat transfer fluid, as well as the system's current and voltage, was measured every 30 minutes. The experimental testing facilities are depicted in Figure 1. 


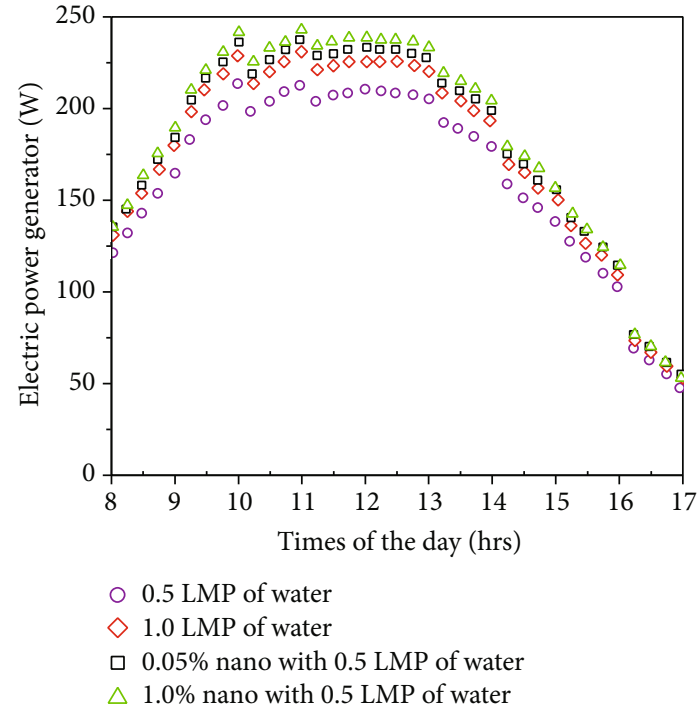

FIGURE 5: Electrical power generation of the water and nanofluid with different flow rates.

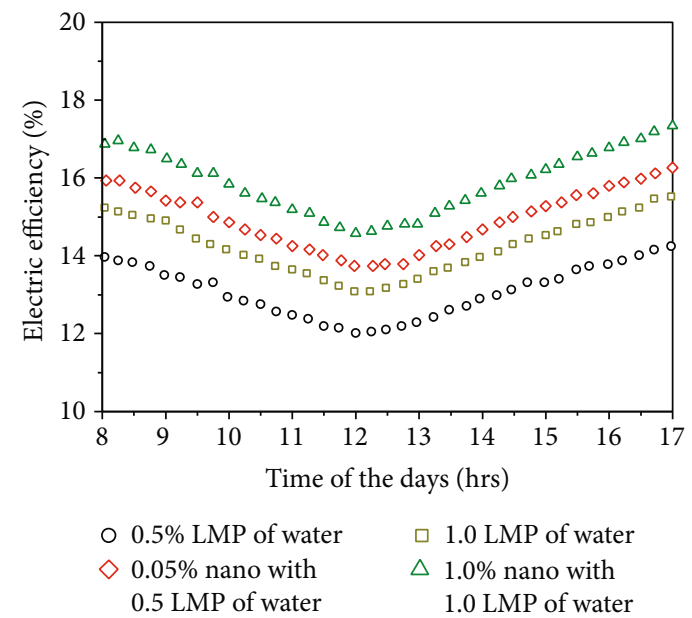

Figure 6: Electrical efficiency of the water and nanofluid with different flow rates.

The experiment was carried out from June to August 2020, with the system-oriented East-West. The photographic view of experimental setup is shown in Figure 1. Schematic view of the architectural design details is displayed in Figure 2. Preparation of nanofluid and its related things are depicted in Figure 3.

\section{Results and Discussion}

The collected data is averaged and provided for further computations and examination at every 15 seconds. The trial days' climatic parameters, solar intensity, and ambient temperature have been accumulated and displayed in Figure 4. The distribution of sun radiation for the duration is a bell form, with the highest rate at 12:00 pm being $1017.07 \mathrm{~W} / \mathrm{m}^{2}$ and the lowest values being $307.18 \mathrm{~W} / \mathrm{m}^{2}$ at 7:00 am and $229.29 \mathrm{~W} / \mathrm{m}^{2}$ at $17: 00 \mathrm{pm}$, in step with this

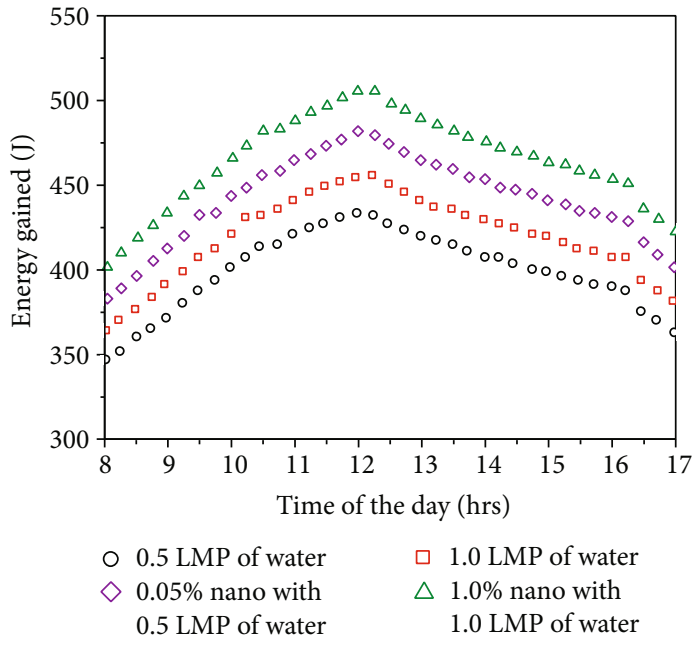

Figure 7: Heat energy gained of the water and nanofluid with different flow rates.

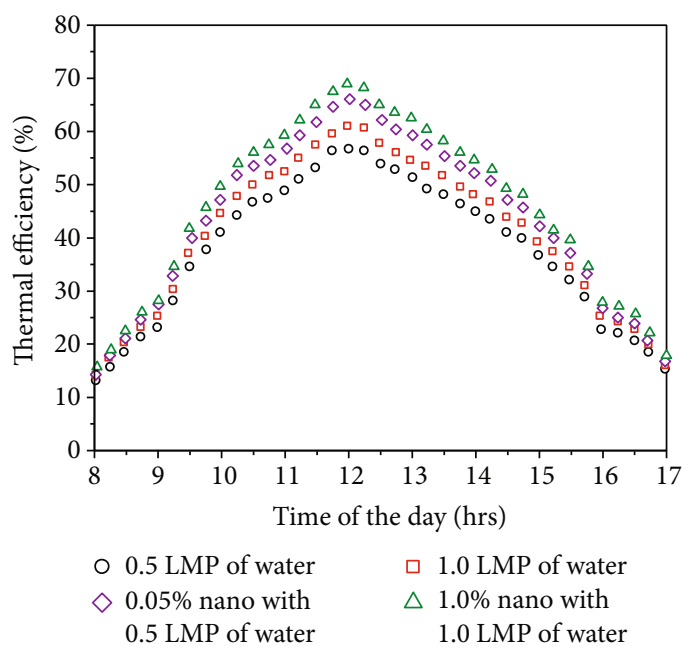

FIgURE 8: Thermal efficiency of the water and nanofluid with different flow rates.

graph. The day-by-day common place ambient temperature climbs from $29.36^{\circ} \mathrm{C}$ at $09: 00$ A.M. to $34.23^{\circ} \mathrm{C}$ at $17: 00$ P.M. The consequences of electrical energy on water and nanofluid waft charges of 0.5 and 1.0 litres in line with minute are shown in Figure 5. Electrical energy grew with time until $12 \mathrm{pm}$ because of developing solar intensity, however, then declined. The common electrical electricity for water is with glide quotes of 0. 5 LPM and 1.0 LPM have become around $46.43 \mathrm{~W}$ and $50.34 \mathrm{~W}$, respectively. Similarly, the common electric-powered electricity for water primarily based graphene nanofluids with 0.05 percent concentrations of 0.5 and 1. Zero LPM becomes $51.81 \mathrm{~W}$ and $53.28 \mathrm{~W}$, respectively. The electrical power of PV panels grew in proportion to the flow rate $[21,22]$.

Figure 6 depicts the impact of electrical efficiency on water and nanofluid flow rates of 0.5 and 1.0 liters per minute. Electrical power decreases with time until 12 p.m. due to increased solar intensity, then increases. The average 
electrical efficiency for water flow rates of 0.5 and 1.0 LPM was around 13.03 percent and 14.19 percent, respectively. Additionally, the average electrical efficiency of waterbased graphene nanofluids with 0.05 percent concentrations of 0.5 and 1.0 LPM was $14.92 \%$, and $15.93 \%$, respectively. Electrical efficiency, like electrical power, and coolent flow rate increased [29]. Figure 7 exposed that, the heat energy gained of the water and nanofluid with different flow rates.

Thermal overall performance of PVT collector with water primarily based on nanofluids has been located at particular drift charges. As seen from Figure 8, maximum thermal overall performance for water at 0.5 LPM turn out to be $56.7 \%$, and $61.2 \%$, respectively. Similarly, a bent had been found for 1.0 LPM for water-based totally graphene nanofluids with $0.05 \%$ attention modified into determined to be $66.3 \%$ and 69 and 5\%, respectively. Thermal normal performance of PVT device changed into more first-class through increasing flow charge due to the reality at higher glide fee temperature distinction among inlet and outlet of $\mathrm{PV} / \mathrm{T}$ device becomes extra due to excessive warmth absorption of nanofluid from tool [29].

\section{Conclusion}

The overall performance of a PVT collector accomplished through water and graphene nanoplatelets-water nanofluid with a concentration of $0.5 \mathrm{wt} \%$ has acheved in this experimental studies. It changed into tested from the factor of view of the first regulation of thermodynamics at regular coolant together with the flow prices of $0.5 \mathrm{~L} / \mathrm{m}$ and $1.0 \mathrm{~L} / \mathrm{m}$, which may be compared. The use of water in the PVT collector complements not unusual each day electric-powered performance with the aid of $8.5 \%$, while using water-based totally graphene nanofluids inside the PVT collector boosts common each day thermal overall performance thru manner of $26.3 \%$.

\section{Data Availability}

The data used to support the findings of this study are included within the article. Should further data or information be required, these are available from the corresponding author upon request.

\section{Disclosure}

This research was performed as a part of the Employment of College of Engineering and Technology, Mettu University, Ethiopia.

\section{Conflicts of Interest}

The authors declare that there are no conflicts of interest regarding the publication of this paper.

\section{Acknowledgments}

The authors thank the Management of Lakireddy Bali Reddy College of Engineering, Sreenidhi Institute of Science and Technology, SV Engineering College, VR Siddhartha Engineering College, and College of Engineering and Technology
Mettu University for providing research supports to complete this research work.

\section{References}

[1] B. J. Brinkworth, B. M. Cross, R. H. Marshall, and H. Yang, "Thermal regulation of photovoltaic cladding," Solar Energy, vol. 61, pp. 169-178, 1997.

[2] S. Yogeshwaran, L. Natrayan, S. Rajaraman, S. Parthasarathi, and S. Nestro, "Experimental investigation on mechanical properties of Epoxy/graphene/fish scale and fermented spinach hybrid bio composite by hand lay-up technique," Materials Today: Proceedings, vol. 37, pp. 1578-1583, 2021.

[3] J. Ji, J. Han, T. Chow et al., "Effect of fluid flow and packing factor on energy performance of a wall-mounted hybrid photovoltaic/water-heating collector system," Energy and Buildings, vol. 38, pp. 1380-1387, 2006.

[4] K. Hemalatha, C. James, L. Natrayan, and V. Swamynadh, "Analysis of RCC T-beam and prestressed concrete box girder bridges super structure under different span conditions," Materials Today: Proceedings, vol. 37, pp. 1507-1516, 2021.

[5] H. M. Bahaidarah, A. A. Baloch, and P. Gandhidasan, "Uniform cooling of photovoltaic panels: a review," Renewable and Sustainable Energy Reviews, vol. 57, pp. 1520-1544, 2016.

[6] M. Sandeep Kauthsa Sharma, S. Umadevi, Y. Sai Sampath et al., "Mechanical behavior of silica fume concrete filled with steel tubular composite column," Advances in Materials Science and Engineering, vol. 2021, 9 pages, 2021.

[7] A. Chauhan, V. V. Tyagi, and S. Anand, "Futuristic approach for thermal management in solar PV/thermal systems with possible applications," Energy Conversion and Management, vol. 163, pp. 314-354, 2018.

[8] R. Suryanarayanan, V. G. Sridhar, L. Natrayan et al., "Improvement on mechanical properties of submerged friction stir joining of dissimilar tailor welded aluminum blanks," Advances in Materials Science and Engineering, vol. 2021, 6 pages, 2021.

[9] A. Merneedi, N. Mohan Rao, L. Natrayan, L. Yuvaraj, and P. Paramasivam, "Free vibration analysis of thick rectangular and elliptical plates with concentric cut-out," Advances in Materials Science and Engineering, vol. 2021, article 7212075, pp. 1-14, 2021.

[10] M. Wolf, "Performance analyses of combined heating and photovoltaic power systems for residences," Energy Convers, vol. 16, pp. 79-90, 1976.

[11] L. Natrayan and A. Merneedi, "Experimental investigation on wear behaviour of bio-waste reinforced fusion fiber composite laminate under various conditions," Materials today: proceedings, vol. 37, no. 2, pp. 1486-1490, 2021.

[12] M. Sardarabadi, M. Passandideh-Fard, and S. Z. Heris, "Experimental investigation of the effects of silica/water nano fluid on PV/T (photovoltaic thermal units)," Energy, vol. 66, pp. 264272,2014

[13] M. Ghadiri, M. Sardarabadi, M. Passandideh-fard, and A. J. Moghadam, "Experimental investigation of a PVT system performance using nano ferrofluids," Energy Conversion and Management, vol. 103, pp. 468-476, 2015.

[14] M. Sardarabadi and M. Passandideh-Fard, "Experimental and numerical study of metal oxides/water nanofluids as coolant in photovoltaic thermal systems (PVT)," Solar Energy Materials and Solar Cells, vol. 157, pp. 533-542, 2016. 
[15] A. N. Al-Shamani, K. Sopian, S. Mat, H. A. Hasan, A. M. Abed, and M. H. Ruslan, "Experimental studies of rectangular tube absorber photovoltaic thermal collector with various types of nano fluids under the tropical climate conditions," Energy Conversion and Management, vol. 124, pp. 528-542, 2016.

[16] S. Soltani, A. Kasaeian, H. Sarrafha, and D. Wen, "An experimental investigation of a hybrid photovoltaic/thermoelectric system with nanofluid application," Solar Energy, vol. 155, pp. 1033-1043, 2017.

[17] A. H. Al-Waeli, M. T. Chaichan, H. A. Kazem, and K. Sopian, "Comparative study to use nano-( $\mathrm{Al} 2 \mathrm{O} 3, \mathrm{CuO}$, and $\mathrm{SiC})$ with water to enhance photovoltaic thermal PV/T collectors," Energy Conversion and Management, vol. 148, pp. 963-973, 2017.

[18] V. Paranthaman, K. Shanmuga Sundaram, and L. Natrayan, "Influence of $\mathrm{SiC}$ particles on mechanical and microstructural properties of modified interlock friction stir weld lap joint for automotive grade aluminium alloy," SILICON, pp. 1-11, 2021.

[19] S. Aberoumand and A. Jafarimoghaddam, "Mixed convection heat transfer of nanofluids inside curved tubes: An experimental study," Applied Thermal Engineering., vol. 108, pp. 967979, 2016.

[20] D. Veeman, M. V. Shree, P. Sureshkumar et al., "Sustainable development of carbon nanocomposites: synthesis and classification for environmental remediation," Journal of Nanomaterials, vol. 2021, 2021.

[21] B. Srimanickam and A. Saranya, "Thermal performance of single glazing flat plate photovoltaic thermal hybrid system with various air channels," Journal of Testing and Evaluation, vol. 49, no. 3, pp. 2119-2150, 2019.

[22] B. Srimanickam, M. M. Vijayalakshmi, and E. Natarajan, "Energy and exergy efficiency of flat plate PVT collector with forced convection," Journal of Testing and Evaluation, vol. 46, no. 2, pp. 783-797, 2017.

[23] D. Veeman, M. S. Sai, P. Sureshkumar et al., "Additive manufacturing of biopolymers for tissue engineering and regenerative medicine: an overview, potential applications, advancements, and trends," International Journal of Polymer Science, vol. 2021, 20 pages, 2021.

[24] M. R. Salem, M. M. Elsayed, A. A. Abd-Elaziz, and K. M. Elshazly, "Performance enhancement of the photovoltaic cells using Al2O3/PCM mixture and/or water cooling-techniques," Renewable Energy, vol. 138, pp. 876-890, 2019.

[25] A. H. Al-Waeli, K. Sopian, M. T. Chaichan, H. A. Kazem, H. A. Hasan, and A. N. Al-Shamani, "An experimental investigation of $\mathrm{SiC}$ nanofluid as a base-fluid for a photovoltaic thermal PV/T system," Energy Conversion and Management, vol. 142, pp. 547-558, 2017.

[26] N. E. Hjerrild, S. Mesgari, F. Crisostomo, J. A. Scott, and R. Amal, "Hybrid PV/T enhancement using selectively absorbing Ag-SiO2/carbon nanofluids," Solar Energy Materials \& Solar Cells, vol. 147, pp. 281-287, 2016.

[27] V. Paranthaman, K. Shanmuga Sundaram, and L. Natrayan, "Effect of silica content on mechanical and microstructure behaviour of resistance spot welded advanced automotive TRIP steels," Silicon, vol. 1, pp. 1-10, 2021.
[28] A. H. Al-Waeli, H. A. Kazem, J. H. Yousif, M. T. Chaichan, and K. Sopian, "Mathematical and neural network modeling for predicting and analyzing of nanofluid-nano PCM photovoltaic thermal systems performance," Renewable Energy, vol. 145, pp. 963-980, 2020.

[29] A. Hassan, A. Wahab, M. A. Qasim et al., "Thermal management and uniform temperature regulation of photovoltaic modules using hybrid phase change materials-nanofluids system," RenewableEnergy, vol. 145, pp. 282-293, 2020. 